\title{
Respect for every living being - Theological perspectives on the bioethical imperative
}

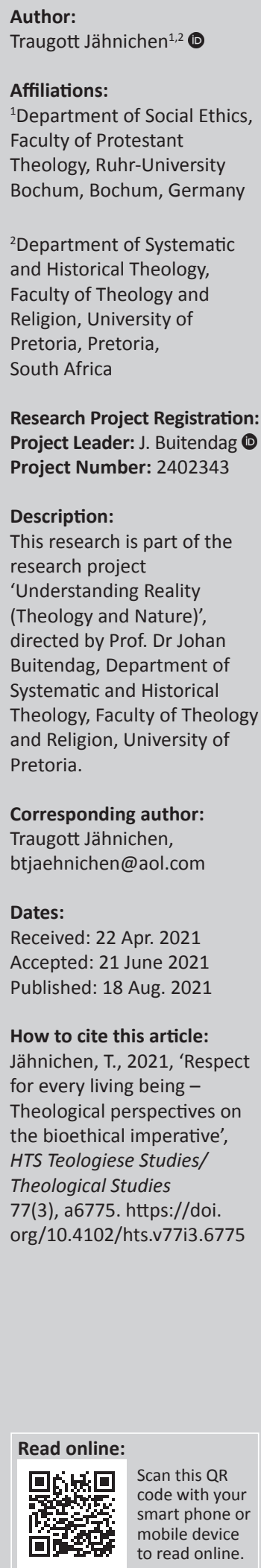

Without ethical embedding, scientific and technological progress is unleashing more and more destructive consequences. In contrast to the 'forgetfulness of nature' of the rationalist worldview, a fundamental reorientation of thinking and the understanding of science are also required to safeguard the integrity of creation, especially the dignity of the human person. Modern 'risk societies' are challenged to self-reflexively adjust to the ambivalent consequences of scientifictechnical civilisation. One impulse of theology lies in pointing out the perspective of a renewed bioethical imperative from the perspective of Christian ethics of Creation, based on the biblical understanding of creation, which embeds human beings in the whole of creation and at the same time singles them out in a special way as the image of God and calls them to responsibility. The theological traditions that have been partially suppressed in modernity can make an important contribution to the development of a vision of fundamental ethical values for ecological responsibility.

Contribution: The following contribution addresses basic questions of understanding nature to expand the one-sided world view of classical rationalism. In doing so, the recognition of biblical traditions plays a central role for reorientation. Only in the horizon of a changed world view, can ethical impulses unfold their effectiveness.

Keywords: ethics of responsibility; integrity of creation; vision of basic values; bioethical imperative; biblical traditions.

\section{Introduction}

The profound ambivalence of scientific and technological progress is now more apparent than ever and, for this reason, 'we urgently need a shared vision of basic values to provide an ethical foundation for the emerging world community' (ECI 2000). In particular, this means 'respect and care for the community of life with understanding, compassion, and love' (ECI 2000). Very early on, Schweitzer (1980/1952) already took a very similar position:

When, towards the end of the [19th] century, people began reviewing and perusing all areas of life with the aim of determining and assessing their achievements, this was done with what, to my mind, was unbelievable optimism ... The ethical perfection of the individual as well as of society must be regarded as being of the essence of culture ... Notwithstanding the importance that is to be attached to the achievements of knowledge and skill, it is nevertheless obvious that only a humanity that strives towards ethical goals can ever fully share in the blessings of material progress and master the hazards that come with it. (pp. 111, 113)

These statements have turned out to be well-nigh prophetic because - apart from a very few exceptions - it was not until well into the 20th century that public attention began to focus on the problematic consequences and, at times, dramatic threats posed by scientific and technological civilisation, problems which Schweitzer had addressed. It is essential that human aspirations towards control of and disposal over nature and its forces - which, especially in the modern era, have tended to take on absolutist character - be overcome, as should corresponding projects for a total technical restructuring of existing reality. In this sense, ecological action alone is not enough, but what is needed to bring about real sustainability is 'a change of heart, mind, attitudes, daily habits and forms of praxis (Rm 12:1-2)' (The Wuppertal Call 2019:11). In discussing the perspective of a bioethical imperative, this text aims to contribute towards the ongoing process.

\section{Towards an ethics of responsibility}

Hans Jonas has trenchantly compared this situation of humanity in the modern era with Prometheus unchained, 'to whom science gives unprecedented powers and the economy a restless impulse' (Jonas 1984:7). Modern societies with their aim of combating scarcity in all its

Copyright: (C) 2021. The Authors. Licensee: AOSIS. This work is licensed under the Creative Commons Attribution License. Note: Special Collection: Theology and Nature, sub-edited by Johan Buitendag (University of Pretoria). 
forms are determined by powerful growth dynamics. This is the logic that underlies the driving impulse of the modern economy, which Jonas so trenchantly describes as the 'restless impulse' (Jonas 1984:7). The issue here is not primarily one of the individual ethics' category of greed or avarice, but rather of a systemic context that is essentially shaped by the characteristic compulsion of capitalist economies to increase invested capital and, tendentially, towards unlimited growth.

In conjunction with the opportunities offered by modern technology, which have led to an immense expansion of human potential and abilities, there is also a concomitant increase of the risk that these opportunities could at any time suddenly come to pose a dramatic threat to humanity. Coining a term that has become a classic, Ulrich Beck described this concept with the words 'risk society'. The starting point for Beck's observations is the diagnosis that, in the advanced or late-modern era, 'the social production of riches systematically goes hand in hand with the social production of risks' (Beck 1986:25). These risks arise through science- and technology-based production processes and through general advances in the supply of goods, whereby it is primarily possible to distinguish between ecological and social hazard situations, that is, 'pollutant distributions' (Beck 1986:31), such as smog, radioactivity and, especially, $\mathrm{CO}_{2}$ emissions, with the consequence of global warming on the one hand and with social consequences such as unemployment and situations of poverty on the other hand. A striking characteristic of the risk society is the global reach, not only but especially, of ecological hazards which know no national borders. Moreover, these hazards, such as nuclear or chemical substances, are often invisible or, like global warming, only visible over longer periods of time and thus difficult for individuals to recognise. Accordingly, they can often only be adequately perceived with the help of experts and elaborate diagnostic methods. In the light of this, the observation and analysis of the consequences of human action have become a pivotal new task for the sciences. ${ }^{1}$

In view of these challenges, Hans Jonas calls for a new ethics of self-restraint in the exercise of human power and of responsibility towards future generations. Especially the high degree of control over nature and its forces - which, on the basis of knowledge in the field of genetics, has the potential to impact swiftly and with far-reaching consequences on the structures of life and, increasingly, on the very nature of human beings, possibly even manipulating them - leads to a situation which, 'in terms both of manner and of magnitude' (Jonas 1984:7), is wholly unprecedented and in the light of which, according to Jonas, all previous ethics prove to be inadequate. The most pressing task, therefore, is the need to

1.The diagnosis that describes the present (geological) era as 'Anthropocene' rests on the observation that human action and activity have a substantial influence on the shape of the earth. This description signalises a new understanding in the field of shape of the earth. This description signalises a new understanding in the field of the academic sciences that is self-critical of human intervention in and impact on nature. According to this, the Holocene - the 'wholly new' age of the warmth phase since the Neolithic period - has, over the past 200 years, been superseded by the Anthropocene, since geological data (sedimentary deposits, etc.) and climate dat now document a dominant influence of humanity on the shape of the earth and it is no longer possible - as in previous eras - to distinguish sharply between cultura and natural phenomena. This concise term was introduced into the scientific and academic debate in the year 2000 by Crutzen (2011). develop new forms of ethical orientation. Because their primary focus has been on the sphere of immediate interhuman relations and is thus of restricted orientation in terms of time and space, traditional ethics are faced with fundamentally different challenges with respect to the remote or long-distance effects that modern technology brings to the potential scope of human action. In this regard, knowledge, especially 'predictive knowledge' (Jonas 1984:28) in the sense of assessing consequences and making prognoses, has a new role to play, because 'the gulf between effect of foreknowledge and potency of action ... [creates] a new ethical problem' (Jonas 1984:28). The discernment of this limited foreknowledge and the subsequent acknowledgement of a certain unknowing that leads to an uncertainty of action thus becomes a constraint on ethics, which is required to incorporate far-distant spatial and temporal consequences in the formation of ethical judgements. In addition to this new order of 'scale of remote impact', 'its irreversibility' (Jonas 1984:9) - which can fundamentally change the living conditions and conditions of survival of many species and, not the least, of humanity - also often requires a new form of assuming responsibility.

Seen from the perspective of intellectual history, the phenomenon that nature has become an immediate object of human responsibility is entirely new. The fact that nature's profound changeability in consequence of technological influences and, in this connection, its vulnerability on account of the extended potential of human action should become so dramatically apparent was inconceivable in all previous epochs (cf. Jonas 1984:26f.). The cumulative effects of human intervention in nature, for which there have hitherto been no examples, are particularly to be taken into account as an 'unprecedented factor' (Jonas 1984:27). Human interventions no longer trigger only immediate, controllable and reversible consequences, but lead on account of interlinked and potentially intensifying ancillary consequences to effects that mostly remain unpredictable for a longer period of time and are in many cases no longer possible to rectify. The military and the peaceful use of nuclear energy can be cited as examples of this, with which humanity has intervened in nature since the 1940s in a wholly unprecedented manner:

In nature, this power serves to lend cohesion to the material world ... but fissioned atoms take a great deal of time to come to rest. To be more precise, they might not come to rest until in around 25,000 years. (Spaemann 2011:11)

By way of example, Robert Spaemann characterises this extreme form of interference with nature as an irresponsible wager, which jeopardises the habitability of parts of our planet for millennia', simply 'in order to maintain our present standard of living' (Spaemann 2011:11). ${ }^{2}$ In the worst-case scenario, the elimination of human life, perhaps even of all life, is conceivable. In view of this danger, Hans Jonas, taking up Kant's categorical imperative and developing it further, has formulated for the present day the following imperative 'that fits better to the new type of

2.Spaemann already recognises a dramatic incursion of humanity in the civilian use of nuclear energy, not only in its military use, since 'the unleashing of this kind of energy [is] ... in itself already the beginning of the unpeaceful' (Spaemann 2011:10). 
human action': 'Act in such a way that the effects of your action are compatible with the permanence of genuine human life on earth' (Jonas 1984:36). ${ }^{3}$

As a consequence of the dramatic depth of intervention of human technologies, a question poses itself going beyond the future integrity of human life: To what extent humans have a special onus of responsibility beyond their own selfinterest with regard to the state of non- or extra-human nature? The 'acknowledgement of objectives in their own right beyond the sphere of the human' implies a human 'custodian role', for which there was no model in classical ethical concepts - at least not 'outside of religion' (Jonas 1984:29). Accordingly, the rationale for human responsibility over against nature extends - implicitly in Jonas, explicitly in Spaemann (2011) - into the sphere of metaphysics (cf. Jonas 1984:8) or calls directly for a religious relationship towards nature:

Only if humankind transcends the anthropocentric perspective now and learns to respect the richness of all life as a value in its own right, only in a religious relationship towards nature of whatever rationale will humankind be in a position to secure in the long term the basis for the existence of humanity in conditions that are fit for human habitation. (p. 38)

However, such a relationship with nature, that is fundamentally religious in character, has largely become lost since the beginning of the modern era.

Instead, the dominant traditional line of modern thinking is characterised by an objectifying view of nature, which, by discerning its (nature's) laws, rendered possible a mastery over nature which had previously been inconceivable and an unparalleled improvement in the provision of goods for humanity. At the same time, it is possible to interpret this attitude, as Günter Altner does, as a problematic 'forgetfulness of nature': Namely, it perceives nature solely and exclusively as the object of scientific analysis and to be technologically mastered and subdued. The notion that nature:

$[H]$ as to serve as object, resource and utility for humanity and nothing else besides, is the fundamental dogma of technical and industrial progress such as being implemented today with an increasingly rapid dynamism. (Altner 1991:2)

In view of this constellation - as it were, foundational to the ethics of responsibility - the question must be raised to what extent the remembrance of the biblical creation narratives is able to disclose new perspectives on the perception of nature and to mediate new bio-ethical stimuli.

\section{Ethical implications of the biblical understanding of creation}

The biblical understanding of creation implies the commissioning of humanity as God's mandatary, without thereby exalting humans to the status of 'lord and master

3.Jonas offers further variations on this imperative, positive and negative formulas, by calling for the 'future integrity of humanity as co-object of your will' and or 'noncalling for the 'future integrity of humanity as co-object of your will' and or 'non-
destructive' effects of human action 'for the indefinite continued existence of destructive' effects of human action '
humanity on earth' (Jonas 1984:36). over nature' (Descartes 2013:section 6). ${ }^{4}$ The term creation itself already gives succinct expression to the perspective that nature should not be entirely relinquished to the objectivisation and disposability of human beings. Creation denotes a gift entrusted by God to humanity, whose duty in terms of Genesis 2:15 is 'to till it and keep it'. In this creation, human beings live in close symbiosis with the animals - as is conveyed, for example, in the instructions for a vegetarian diet in Genesis 1:29f. In correspondence to the source of this motif in the ancient Egyptian kingship ideology, the central status of humans in the image of God in creation originally implies a responsible and caring attitude, which, in the Hebrew bible, is henceforth conferred on all people and is to be demonstrated with regard to their handling of creation. In this sense, precisely, this commissioning of human beings to exercise dominion (Gn 1:28), which was interpreted in the early modern period - prominently by Francis Bacon and René Descartes - as an instruction to dominate and subjugate nature and, to that extent, has had an ambivalent historical influence, must be stated more precisely. It concerns humanity's dealings with animals, for which traditional translations use the term: 'have dominion' - and in the context of an agricultural civilisation and its general dealing with nature: 'subdue it'. The term used to describe this dominion over the animal world is to be encountered in various biblical passages as equivalent to the notion of a flock being led by a caring shepherd (cf. Ezk 34:3, Ps 49:15), whereby not so much a model of rigid rule is implied as one of nurturing guidance of the animals. To 'subdue' the earth likewise does not mean ruthless subjugation, but humans are called to make the earth habitable and to shape it by their work. The interpretation of the commission to exercise dominion in Genesis 1:28 is thus to be understood in analogy to Genesis 2:15 ('to till it and keep it'), according to which humans, even though theirs is a forming role, are yet required to be preservers (cf. Ebach 1989:98-129; Rüterswörden 1993).

In addition to this, areas that are beyond or withdrawn from human disposing are characteristic for creation in a biblical perspective, as is made clear in God's answer out of the whirlwind in the Book of Job or in Psalm 104. Consequently, by no means, all facets of creation pertain to the needs of human beings. In this sense, for example, the creation of the primordial mythical creature 'Leviathan' can specifically not be categorised according to the principles of human rational expediency or exploitability (cf. Ebach 1984:49), but God created Leviathan as his 'plaything' (cf. Ps 104:26). These biblical texts thus mark a clear boundary over against the concept of an unlimited human power of disposition that encompasses the whole of creation. Several areas of creation cannot be constrained by 'the principles of human-oriented usefulness', but rather they contribute 'to the diversity of the world, which is not envisioned as anthropocentric, but as strictly theocentric' (Ebach 1984:49f.).

4.According to Descartes, a proper knowledge of the powers of nature and the activities of the tradesman - in today's context: natural sciences and engineering sciences - allow humans to become 'lord and master over nature'. 
The transgression of humanity's relation to God, self and the world as consequence of the narrative of the Fall leads directly to a transgression of the duties of preservation and formation inherent in creation. This human transgression is reflected not only in fratricide (Gn 4:1-16), but, beyond that, in a latently violent culture (Gn 4:17ff.) and in hybrid mega-projects (cf. Gn 11:1-9). By contrast, the new legal order for peaceful coexistence constituted by the covenant between God and the people of Israel includes the whole of creation. Thus, for example, the Sabbath rest commandment equally embraces humans and animals (Ex 20:10, Dt 5:14), the same applies for the provisions governing the sabbatical year and the year of jubilee (cf. Lv 25). The Sabbath rule gives expression par excellence to a lifepromoting attitude towards fellow human beings and towards nature that is in accordance with the divine will, established as it is in the creation narrative and in the Exodus event and, besides determining the weekly rhythm of days, resulting through the institution of the sabbatical year in 'rest' for the land and, at a later period, in the cancellation of debt as well as, in the year of jubilee, the re-establishment of ownership structures and is thus intended to determine the entire rhythm of life in Israel (cf. Crüsemann 1992:157-162, 264-269).

From this perspective, creation encompasses the entirety of land, plants, animals and humans, each of them, respectively, co-related to their Creator and thereby also to each other. To this extent, creation has its own intrinsic value from a biblical perspective, ${ }^{5}$ because it is not entirely at humanity's disposal, thereby overcoming a purely anthropocentric perspective notwithstanding humanity's special dominion status and protective responsibility. The co-creation is established by God, quintessentially related to him, and is provided for with far-reaching protective rights in the biblical law system. Ultimately, this also includes providing for a long-term oriented perspective on human intervention in nature, to safeguard successive generations of the animals in the sense of the present-day conservation of species (cf. Wustmans 2015:96-106). By way of example, the instruction in Deuteronomy 22:6ff. can be called to mind, in accordance with which it is permissible to take eggs out of a bird's nest, but the mother bird must be protected: 'Let the mother go, taking only the young for yourself, in order that it may go well with you and you may live long'. The promise of a long life that is to be found here, and which is also prominently present in the parental commandment of the Decalogue, can be interpreted without further ado as 'safeguarding of successive generations' (cf. Ebach 2012:12), because the purpose of sparing the mother bird consists primarily in ensuring the continued existence of the species.

\section{The 'renewed' bioethical imperative}

The ethical consequences of the understanding of creation outlined have frequently been suppressed or replaced in Christian cultures and even by the churches themselves.

5.The farther-reaching question as to whether humans have an obligation to ascribe analogous legal claims, in the sense of intrinsic or inherent rights in nature, to
animals, plants, the soil and other factors of the eco-system is discussed in MeyerAbich (1989:254-276).
In this sense, international consultations of the churches, often acting in ecumenical solidarity - and in some cases together with various other religious groups - emphasise their ethical responsibility towards creation by self-critically confessing as a sin the failure of the churches to adequately discharge their duty of stewardship towards creation. 'Churches have not always offered balanced theologies and praxes on stewardship of (or care for) life' (Dar es Salaam Statement 2007:2). There are poignant reminders of the 'groaning of creation' and its yearning to be saved (cf. Rm 8:22ff., quoted in the Accra Confession 2004 and in the Wuppertal Call 2019:10ff.). At the same time, the representatives of the churches uncompromisingly call for a repentance or conversion in favour of life, an 'ecological conversion (metanoia)' (The Wuppertal Call 2019:11) and/or 'metanoia' (radical transformation) (Dar es Salaam Statement 2007:4), with the aim of proclaiming 'Life for all in Fullness' (Accra Confession 2004). An essential element of this is to clarify in detail the theological principles for the integrity of creation and to commit oneself to that effect. In these documents, along similar lines to the 'Earth Charter', the earth is referred to as 'home' or, by Pope Francis, as 'our common home' (Franziskus 2015) 6 and 'respect' is called for with regard to how we behave towards nature.

In taking up and concretising these fundamental stimuli, the development prospects of life in the open process of evolution must, therefore, remain ensured in the process of human intervention in nature (cf. Altner 1991:2). Expressed in positive terms, it is a question of guaranteeing a course of action that serves life in 'agreement with creation' (EKD 1991). Technical viability and economical utility should not be allowed to be the sole factors for scientific development, but must also include the perspective of improving living conditions both for humanity and for creaturely life as a whole in the sense of ensuring the 'integrity' of creation. Because, from a theological perspective, human beings exist a close relationship to all other creatures, being as it were 'embedded' in creation, they must therefore preserve the ethos of their fellow creatures in their actions. Human beings and their fellow creatures have an enduring reference to the Creator. All creatures have in common their shared relatedness or referentiality towards the Creator, who called them into being. By virtue of having the 'breath of life' breathed into them, humans and animals can be distinguished from the plants, corresponding to the differentiation of the days of creation in the first creation narrative, as can the living part of creation be distinguished from inanimate nature. Humankind alone is ultimately determined by God as mandatary with the task of caring dominion. Nonetheless, this sequence should not be hastily taken as justification for an apparently 'natural' hierarchy of life with correspondingly graded rights of protection.

In the light of this, Albert Schweitzer's consciously, nonhierarchically, bio-centrically conceived 'ethics of reverence for life' and the theologian Fritz Jahr's first draft of a bio-ethics from 6.This is the subtitle of the encyclical Laudato si: Pope Francis, Laudato si. On care for our common home. 
the perspective of the history of science both pose a creationtheology and creation-ethics challenge that is still relevant today. A classic expression of this approach is to be found in a posthumously published article by Schweitzer (1967):

The man who has become thoughtful in this manner experiences at the same time the necessity of offering to every will to live the same reverence for life that he offers to his own. Good, then, for him means to preserve and promote life, raise life capable of developing to its highest worth. Evil, for him, means harming or destroying life capable of developing in its own development. This is the absolute fundamental principle necessary for ethical thinking. (p. 9f.) $)^{7}$

Schweitzer shows equal regard for and pays equal reverence towards all life. Human beings can and ought to recognise and respect an independent will to live in each and every other life, including plant life. Schweitzer rejected every type of upgrading of particular life forms, although he recognised as given the need for weighing up the will to live in concrete action and decision-making - the need as a doctor to save human lives by fighting against viruses or to feed animals with other animals, etc. Nevertheless, he always consistently interpreted the repeated need for the act of destroying life, even at the level of viruses, as an expression of the 'selfdivision of the will to live' (cf. Schweitzer 1981:334) and, with regard to human action, as guilt or complicity.

Borrowing from the end-in-itself or autotelic formula of Kant's categorical imperative, Fritz Jahr was the first scholar to formulate a new bioethical imperative: 'As a matter of principle, respect every living being as an end in itself and treat it wherever possible as such!' (Jahr 1927:2). Consequently, not only human beings, but explicitly all living beings are also to be respected as ends in themselves. In the study by Kant, the corresponding formula meant that every person, irrespective of the context in which people encounter each other, exists as an end in himself or herself and should therefore always be treated 'as an end, never merely as a means to an end' (Kant [1786] 1956:61). This emphasis is relinquished in Jahr's differentiating formulation when he introduces the distinction, whereby every living being is indeed to be respected as an end in itself, but is only to be treated 'wherever possible' (Jahr 1927:2) as end in itself. For the one part, Jahr thus makes clear the difficulties involved in a universal autotelicity of all creatures and relativises the unconditionality of maintaining that autotelicity. But even when humans use animals or plants for their own purposes solely as a means to an end, which is de facto the case with every intake of food, these fellow creatures are to be respected as ends in themselves. This concept of the bioethical imperative thus goes clearly beyond the imperative formulated by Hans Jonas, which is essentially targeted on the permanence of human life. ${ }^{8}$ Taking this stimulus seriously

7.In his "Culture and Ethics' (first published 1923), Schweitzer expressed himself somewhat more cautiously: 'To preserve and promote life is good; to destroy and inhibit life is evil' (Schweitzer 1981:331).

8.'Wherever the breeding of animals views them only as a mass of meat ..., wherever the ecological niche in which every species is endemic is defined from the outset by the slaughterhouse, the basis of symbiotic interaction with living beings has been abandoned' (Spaemann 2011:34). would necessarily imply a changed perception of non-human creation and, ultimately, changed approaches to it and different actions resulting from that. In the sense of Jahr's bioethical imperative, the manner of treating the so-called livestock or crop plants, for instance, therefore has to at least reflect respect for these living creatures, and they should not be, as it were, exploited or commercialised in a functionalistic manner solely for human ends.

Each in their own way, Schweitzer and Jahr emphasise that this autotelicity in the sense of reverence or respect is due not only to humans, but also to all living beings, corresponding to the theological concept of fellow creatureliness. Nevertheless, a fundamental difference also ultimately remains in their conceptions, reserving the concept of dignity in the strict sense only for humans. However - taking on biblical traditions - it is certainly possible to talk of the intrinsic value of animals, plants and even of inanimate nature. Fellow creatures are, therefore, not to be viewed - as has mostly been the case in the tradition of the modern era - as mere objects, but they should be perceived as subjects, esteemed and protected with the goal of maintaining biodiversity (cf. Huber 2006:362-381). Because no creature - a theological idea which Pope Francis interprets pointedly - 'is superfluous', but rather, as part of the universe, 'speaks of God's love' (Franziskus 2015:No. 84), the dramatic extinction of species means that:

Because of us, thousands of species will no longer give glory to God by their very existence nor (be able to) convey their message to us. We have no such right. (No. 33)

In this respect, the protection of species is a direct consequence of the creation-ethics stimulus of the Bible and of the bioethical imperative deducible from it. Irrespective of this non-hierarchical, biocentric approach, it is often necessary in the interests of species protection to take a relatively hierarchical or graded stance on conservation value, frequently entailing a difficult weighing of interests. It is not always possible for all species and or all living beings to be protected to the same degree and, for example, it is even conceivable in special individual cases for plants to be given precedence over animals in the interests of securing the highest possible biodiversity. ${ }^{9}$ To this extent, the different grades of conservation value, which are partially governed by special legislation and which in any case are insufficiently developed in almost all countries, ${ }^{10}$ need to be modified.

\section{Outlook: The special status of humanity in creation}

From a biblical viewpoint, humankind is clearly singled out in the context of creation. Even if the term 'anthropocentrism' is inapplicable for many reasons, humans are nevertheless

9.Cf. Wustmans (2015:132ff.), who discusses the scenario, whereby an overly large population of elephants in certain regions, where there are hunting and other restrictions can destroy all plants, especially trees and that it could, therefore, be possible in the interests of biodiversity to permit their controlled shooting.

10.German law differentiates in this sense between the protection of animals and safeguarding natural resources. There are different legal codifications for this with differentiated legal consequences which, with regard to protection rights, still remain inadequate. 
commissioned to be 'rulers' over the 'work' of creation (cf. Ps 8:6). Accordingly, humanity's status and opportunities for action are unique compared with the rest of (fellow-) creation, ${ }^{11}$ even though they too are limited. Talk of humankind as created co-creator' (cf. Hefner 1984:296-362) ${ }^{12}$ is, therefore, problematic. Instead, humans are and remain creaturely in their distinguished yet at the same time restricted role of cooperator Dei. This theological location of humankind should be taken into consideration, especially in view of the developmentand use of technologicalinnovations. Thathumans are allowed to intervene in creation is perfectly consistent with the distinction of humans in terms of Genesis 1:28 or Psalm 8:7f. The crucial point, however, is to differentiate the various types of human intervention according to how profound their effects are, how rapid they are and what their consequences are. The question as to whether, where and, where applicable, to what extent attempts at co-creatio take the place of cooperatio marks a central criterion of demarcation from a theological perspective. Possible examples of overstepping this boundary are - recalling Jonas' argumentation - the initiation of non-reversible processes that destroy natural resources that can thus be described as posing a threat both to the 'Dasein' and to the 'So-Sein' - to the very existence and the kind of existence - of creation (cf. Jonas 1984:86ff.).

Irrespective of its special status, humanity therefore always remains a part of creation as a 'natural creature', the limits of which not even transhumanism is able to bypass. As a creature of nature, humankind remains reliant on 'community' with the other creatures of nature. Not even their own life is of their own doing, but they live out of the sustaining companionship and blessing of God. Humanity remains dependent on God as the giver of life and of all gifts. This is expressed most poignantly in the trusting plea for 'daily' bread (cf. Mt 6:11 and parallels), which stands in marked contrast to the uninhibited momentum of economic activity with its compulsion towards constantly increasing growth. The question is far rather how - primarily in the richer nations of the world to put an end to the scandal of the exploitation of the South, especially Africa, which predominantly serves 'to sustain the consumerist lifestyles of rich, northern countries' (Dar es Salaam Statement 2007:2) - an ethos of 'contentment' can be developed that recognises the limits of nature as opposed to the pressure for unrestricted (economic) growth. In the light of this, it is necessary to devise a lifestyle that is consistent with the resources and, not the least, the limited absorptive capacity of the earth with regard to the emission of all kinds of pollutants.

This realisation of humankind's dominion yet simultaneously restricted place in the wholeness of creation is to be understood as an expression of a theologically enlightened awareness of human freedom. From a theological perspective, freedom is always 'communicative and cooperative freedom'

11.cf. Psalm 8:5: The Psalmist confesses before God in prayer: "You made them (humankind) a little lower than God'.

12.The American Lutheran theologian Philip Hefner coined and popularised the notion of humankind as created co-creator'. By contrast, it is to be remembered that the Hebrew word for 'create' (bara) in the Hebrew bible refers exclusively to God and thus denotes a strict separation from all human action.
(Huber 1999:180), which sets the individual in responsibility before God, and his or her fellow humans and fellow creation. To this extent, and on account of the finiteness of human knowledge - humans are never able to see or know 'fully' (cf. 1 Cor 13:12) nor are all things 'fully' at their disposal - the freedom of scientific research and economic activities especially require to be responsibly organised and developed. The theologically grounded recognition of the need for a self-limitation of human action is thus the anthropological consequence of the bioethical imperative.

\section{Acknowledgements}

The author owes gratitude to Prof. J. Buitendag who invited him to participate in this research project of Theology and Nature.

\section{Competing interests}

The author declares that he has no financial or personal relationships that may have inappropriately influenced him in writing this article.

\section{Author's contributions}

T.J. is the sole author of this article.

\section{Ethical considerations}

This article followed all ethical standards for research without direct contact with human or animal subjects.

\section{Funding information}

This research received no specific grant from any funding agency in the public, commercial or not-for-profit sectors.

\section{Data availability}

Data sharing is not applicable to this article as no new data were created or analysed in this study.

\section{Disclaimer}

The views and opinions expressed in this article are those of the author and do not necessarily reflect the official policy or position of any affiliated agency of the author.

\section{References}

Altner, G., 1991, Naturvergessenheit, Grundlagen einer umfassenden Bioethik, Darmstadt.

Beck, U., 1986, Risikogesellschaft, Auf dem Weg in eine andere Moderne, Frankfurt.

Crüsemann, F., 1992, Die Tora, Theologie und Sozialgeschichte des alttestamentlichen Gesetzes, Munich.

Crutzen, P.J., Davies, M., Mastrandrea, M.D., Schneider, S.H. \& Sloterdijk, P., 2011, Das Raumschiff Erde hat keinen Notausgang, Energie und Politik im Anthropozän, Berlin.

Dar es Salaam Statement on Linking Poverty, Wealth and Ecology, 2007, Filed under: Poverty, wealth, ecology, social and economic development, viewed n.d., from www.wcc.org

Descartes, R., 2013, Traktat über die Methode richtig zu denken, transl. and ed. Christian Wohlers, Felix Meiner Verlag, Hamburg. 
Earth Charter International (ECI), 2000, The Earth Charter, viewed n.d., from viewed from https://earthcharter.org/.

Ebach, J., 1984, Leviathan und Behemot: Eine biblische Erinnerung wider die Kolonisierung der Lebenswelt durch das Prinzip der Zweckrationalität, Schöningh, Paderborn.

Ebach, J., 1989, 'Schöpfung in der hebräischen Bibel', in G. Altner (ed.), Ökologische Theologie, pp. 98-129, Perspektiven zur Orientierung, Stuttgart.

Ebach, J., 2012, 'Zwischen Lebenskampf und Utopie: Die Tiere im Alten Testament', in T. Jähnichen \& C. Wustmans (eds.), Tierethik: Biblisch-historische Grundlagen, Normative Perspektiven, pp. 9-17, Aktuelle Herausforderungen, Kamen.

Evangelische Kirche in Deutschland (EKD), 1991, Einverständnis mit der Schöpfung, Ein Beitrag zur ethischen Urteilsbildung im Blick auf die Gentechnik, Gütersloh.

Franziskus, 2015, Laudato si. Über die Sorge für das gemeinsame Haus, Die UmweltEnzyklika mit Einführung und Themenschlüssel, mit einer Einführung von Christiane Florin, Stuttgart.

Hefner, P., 1984, 'The doctrine of creation', in C.E. Braaten \& R.W. Jenson (ed.), Christian Dogmatics: The creation, pp. 269-362, Fortress Press, Philadelphia, PA.

Huber, W., 1999, Kirche in der Zeitenwende, Gesellschaftlicher Wandel und Erneuerung der Kirche, Gütersloh.

Huber, W., 2006, Gerechtigkeit und Recht, 3rd edn., Grundlinien christlicher Rechtsethik, Gütersloh.

Jahr, F., 1927, 'Bio-Ethik. Eine Umschau über die ethischen Beziehungen des Menschen zu Tier und Pflanze', Kosmos: Handweiser für Naturfreunde und Zentralblatt für das naturwissenschaftliche Bildungs- und Sammelwesen, 24, 2-4.

Jonas, H., 1984, Das Prinzip Verantwortung, Versuch einer Ethik für die technologische Zivilisation, Frankfurt/Main.
Kant, I., [1786] 1956-1964, 'Grundlegung der Metaphysik der Sitten', in W. Weischede (ed.), ders., Werke in sechs Bänden, Vol. 4, Insel Verlag, Wiesbaden.

Meyer-Abich, K.M., 1989, 'Eigenwert der natürlichen Mitwelt und Rechtsgemeinschaft der Natur', in G. Altner (ed.), Okologische Theologie: Perspektiven zur Orientierung, pp. 254-276, Kreuz Verlag, Stuttgart.

Rüterswörden, U., 1993, Dominium Terrae, Studien zur Genese einer alttestamentlichen Vorstellung, Berlin.

Schweitzer, A., 1967, 'Wort an die Menschen', Schweizerisches Reformiertes Volksblatt (2), 9f.

Schweitzer, A., 1980, Aus meinem Leben und Denken, 1st edn (new edn., 1952)., Frankfurt.

Schweitzer, A., 1981, Kultur und Ethik, 1st edn. (1923), Sonderausgabe mit Einschluss von Verfall und Wiederaufbau der Natur, Verlag C.H. Beck, München.

Spaemann, R., 2011, Nach uns die Kernschmelze, Hybris im atomaren Zeitalter, Stuttgart.

The Accra Confession, 2004, Life for all in fullness, viewed n.d., from www.wcrc.ch/de/ accra.

The Wuppertal Call, 2019, 'Kairos for creation: Confessing hope for the earth', in L. Andrianos, M. Biehl, R. Gütter, J. Motte, A. Parlindungan, T. Sandner \& J. Stork et al. (eds.), The "Wuppertal Call" - Contributions and recommendations from an International conference on eco-theology and ethics of sustainability, pp. 9-12, Department for Justice, Peace and the Integrity of Creation of the United Evangelical Mission, Solingen.

Wustmans, C., 2015, Tierethik als Ethik des Artenschutzes, W. Kohlhammer Verlag, Stuttgart. 